\title{
The Effect of Good Corporate Governance and Corporate Social Responsibility Disclosure on Financial Performance with the Company's Reputation as Moderating
}

\author{
Hermawati $^{1}$, Mediaty ${ }^{2}$, and Yohanis ${ }^{3}$ \\ Magister of Accounting, Faculty of Economic and Business \\ Hasanuddin University, Makassar, Indonesia
}

\begin{abstract}
This study aims to analyze the effect of good corporate governance and corporate social responsibility disclosure on financial performance with the company's reputation as a moderating variable. The population of this study were 20 state-owned companies listed on the BEI. This study uses purposive sampling technique and produces 16 companies with observation years, namely 2014-2019. The analysis technique used to analyze data is Moderated Regression Analysis (MRA). The results showed that good corporate governance does not affect financial performance, disclosure of corporate social responsibility affects financial performance, corporate reputation does not moderate the relationship of good corporate governance to financial performance and corporate reputation does not moderate the relationship of corporate social responsibility disclosure on financial performance.
\end{abstract}

Keywords: Good Corporate Governance, Corporate Social Responsibility, company reputation, financial performance, BUMN.

\section{INTRODUCTION}

Facing the current era of globalization, every company is required to be able to compete so that the company can be superior to other competing companies so that it can achieve the company's goals in the long run and can contribute to the national economy. The company as an economic entity, whatever its form of business, both in the fields of industry, trade and services aims to print optimal profits in order to increase the wealth of shareholders, which can be seen from the presentation of the company's financial performance reports.

State-Owned Enterprises (SOEs) are one of the economic actors in the national economic system. BUMN has a contribution in the Indonesian economy and plays a role in producing various types of goods and services that can realize people's welfare. BUMN is located in various sectors including, agriculture, the forestry sector, the plantation sector, the financial sector, the BUMN sector, the mining sector, the transportation sector, the electricity sector, the trade sector and also the construction sector.
Corporate financial performance is a picture of the achievement of the implementation of an activity or program or policy in realizing the goals, objectives, mission, and vision of the organization. Performance reporting is a reflection of the obligation to present and report on the performance of all activities and all resources that need to be accounted for. Company performance in general will usually be represented in the financial statements. Financial performance evaluation is important in encouraging companies to be more efficient and more selective in their operations to achieve and improve their ability to generate profits.

Efforts to improve financial performance are influenced by various factors. One of them is by doing good corporate governance (good corporate governance). Good corporate governance is a system that regulates and controls companies to be able to create added value for all stakeholders (Sutedi, 2011). The better implementation of good corporate governance will affect the company's performance, this is according to what was revealed by the World Bank (Widjaja and Tunggal, 2012) that corporate governance is a collection of laws, regulations and rules that must be met, which can encourage company performance to work efficiently , generating long-term sustainable economic value for shareholders and the surrounding community as a whole.

According to the Financial and Development Supervisory Agency (BPKP) which underlies the need for GCG seen from practical needs, in the United States must restructure corporate governance caused by market crashes in 1929. Santoso (2017) stated that GCG represented by the proxy for institutional ownership has a significant positive direct effect on firm value. GCG has a significant indirect effect on firm value by using financial performance as an intervening variable. Fitriani and Hapsari (2015) show that GCG has a significant effect on financial performance which is proxied by Return on Assets (ROA). Whereas (Iswara, 2014), Malau et al. (2018) (Malau et al., 2018), Novrianti and Armas (2012) show that GCG has no effect on financial performance. This proves that the issuer's awareness of implementing GCG is still low. 
BUMN as a company that has implemented GCG periodically must publish information as a form of corporate transparency. This information aims to reduce asymmetry between the company and external parties as well as an important element for investors and business people to make investment decisions, so that not only financial statements but reporting disclosure of social responsibility activities (CSR) is needed in the annual report because it will provide more value for companies that will have an impact on a better reputation than companies that do not disclose, as a result the company's performance will increase.

The implementation of CSR is one form of implementation of the concept of GCG as a business entity that is responsible for the community and its environment. GCG is a system that can provide direction and control for the company to carry out and disclose its CSR activities. The implementation of GCG in the company will encourage management to manage the company properly including implementing its social responsibility. Ramdhaningsih and Utama (2013) stated that GCG was related to CSR. CSR is in line with one of the four main principles of GCG, namely responsibility explains that in addition to conveying corporate responsibility in the form of financial reports, companies are also required to report their social and environmental responsibility activities.

The concept of sustainability is carried out by companies to protect the environment so that company needs can be met. Sustainability is carried out covering several factors that can support the company's reputation, including social, economic, and environmental factors. Reputation is one of the main capital to increase the company's goodwill because with a good reputation will be an effective propaganda to increase public and consumer confidence in the business undertaken.

Reputation helps companies build trust and build closer relationships with stakeholders. The importance of reputation for companies and stakeholders encourages independent institutions to reward them. Fortune magazine has published the reputation ranking of America's Most Admired Company (AMAC) since 1984 (Lee and Roh, 2012; Shi, 2016). An award for corporate reputation in Asia was given by Asian Business by introducing Asia's Most Admineried Companies. Frontier Consulting Group held an award in the form of Indonesia's Most Admired Company (IMAC) Award / Corporate Image Award (Frontier Consulting Group, n.d). The purpose of giving awards is to encourage companies to manage reputation in the long run.

A reputable company is a company that has scarce and valuable resources, and is a source of competitive advantage to get above average return (Barney, 1991). The company's reputation includes potentials that can become advantages in market competition. The Company's reputation is gained by integrating a number of considerations between finance, management, advertising and public relations. In the current era of global markets, reputation behavior can be seen from the attention of business people towards financial statements, activities carried out, social and environmental (Misani, 2017).

In this study, reputation is used as a moderating variable that has a bearing on the influence of GCG and CSR in corporate entities. Reputation can improve company performance and give an overview of the company. The implementation of GCG practices is one of the important steps for State-Owned Enterprises (SOEs) to increase and maximize corporate value, encourage professional, transparent and efficient company management by increasing the principles of openness, accountability, trustworthiness, responsibility and fair so that it can fulfill obligations well to shareholders, board of commissioners, business partners, and other stakeholders.

Roberts and Dowling, (2002) also conducted research on corporate reputation and financial performance. The results showed that there was a positive relationship between corporate reputation and financial performance. Based on the results of several previous studies which stated that the company's reputation had a positive effect on financial performance so that reputation used as a moderating variable to determine whether the reputation variable is able to strengthen the relationship between the independent variable and financial performance.

According to Wijs (2013: 330), it was explained that when a company is unable to implement the practice of cooperation between company owners and management (agents), the company does not consistently apply good governance practices so that the company's reputation decreases. This opinion is reinforced by the statement (Siam, et al., 2014), that in accordance with agency theory, the separation between CEO position and chairman position should be carried out. When the company is able to separate the two positions, it means that the company's reputation is good because it follows good corporate governance. According to Phandeirot (2017), corporate reputation is proven to have a positive effect on financial performance. The results of several studies above are the reason researchers to see the effect of the two dependent variables on financial performance when reputation is used as a moderating variable. In this study explains the importance of financial performance in stateowned companies on the Indonesia Stock Exchange. Financial performance can be seen in the financial statements of each company within a certain time period.

\section{LITERATURE REVIEW}

\section{A. Signal Theory}

Akerlof (1970) found that when a buyer does not have a specific product-related information and only has a general perception of the product, the buyer will judge all products at the same price, both low quality products and high quality products, so from that perception will harm the seller with high product quality. Signal theory suggests how a company should give signals to users of financial and non-financial reports. This signal is in the form of information about what management has done to realize the owner's wishes, namely maximizing their profits. 


\section{B. Legitimacy Theory}

Suchman (1995) suggests a broad definition of legitimacy, "Legitimacy is the enterprise stakeholders to the existing system of laws, rules, norms, values, beliefs as the evaluation criteria for corporate activities appropriate, proper and desirable in general perceived or envisaged". Legitimacy can be regarded as equating perceptions or assumptions that actions taken by an entity are actions that are desirable, appropriate or in accordance with a system of norms, values, beliefs and socially developed definitions.

\section{Agency Theory}

The basis for discussing corporate governance is the agency theory of Jensen and Meckling (1976), stating that the agency relationship is a contract between agent (manager) and principle (investor). Conflict of interest between the owner and agent occurs because the possibility of the agent does not always act in accordance with the interests of the principal, thereby triggering agency costs. Corporate governance arises because there is a separation between ownership and company control, or often known as agency problems.

\section{Hypothesis}

As an effort to achieve the motives of existing activities, the Company will continue to strive to improve the performance of workers and the company as a whole. The improved performance of successful companies will impact on the amount of profits and also increase the value of the company in the eyes of investors. As a step to improve performance, efficiency and professionalism then a principle that is believed to be able to encourage an increase in the performance of the company appears, the principle is the principle of Good Corporate Governance (GCG). Fatimah et al., (2017) suggested that Good corporate governance has a significant positive effect on financial performance. Whereas Santoso (2017), shows that GCG has a significant indirect effect on firm value by using financial performance as an intervening variable.

\section{$\mathrm{H} 1$ = Implementation of Good Corporate Governance (GCG) has a positive effect on financial performance.}

Corporate CSR disclosure aims to provide as much positive information about the company as possible to stakeholders and the community. The more positive information obtained by stakeholders and the public, the trust about the company's products and activities will also increase in the eyes of stakeholders. Increased public confidence in the company's products will increase sales which have an impact on increasing profits and company performance. (Saeidi et al., 2015) stated in their research that when consumers are faced with the similarity of product quality and prices from different companies, consumers will prefer products from companies that contribute to environmental management practices. Humanitisri and Ghozali (2018), Djamilah and Surenggono (2017) suggest that and CSR have a positive effect on ROA and ROE financial performance. From the explanation and research results above, it can be concluded that CSR has a positive effect on financial performance. Therefore, the hypothesis can be formulated as follows.

H2 = Disclosure of Corporate Social Responsibility (CSR) has a positive effect on financial performance.

Implementation of GCG has become a necessity for all companies. Seeing the increasingly fierce competition between one company and another, efforts are needed to create good GCG so that company management occurs efficiently and effectively, and company performance increases. According to Egwuonwu (2011), Putri and Hatane, (2016) found that financial performance is also influenced by corporate reputation, and the influence of corporate reputation on financial performance is positive. With a high corporate reputation, it will improve financial performance. Based on the results of several previous studies which stated that the company's reputation has a positive effect on financial performance so that reputation is used as a moderating variable to determine whether the reputation variable is able to strengthen the relationship between the independent variable and financial performance. Therefore, the hypothesis can be formulated as follows.

\section{$\mathrm{H} 3$ = Reputation Has a Positive Effect in Moderating the Relationship Between GCG on Financial Performance}

The effect of CSR on a company's reputation is reflected in stakeholder theory. CSR and disclosure is one way for companies to meet expectations, gain attention, support, and positive impressions from stakeholders and the public. Support and impressions from stakeholders and the community are very influential for business continuity and company reputation. CSR disclosure can be a beneficial element as a corporate strategy, contribute to risk management and maintain relationships that can provide long-term benefits for the company (Heal, 2004). CSR disclosure is one of the company's strategies to achieve company goals. By disclosing CSR the company will get a good image from the public. Based on the description above, the hypotheses that can be formulated are:

H4 = Reputation Has a Positive Impact in Moderating the Relationship between CSR and Financial Performance.

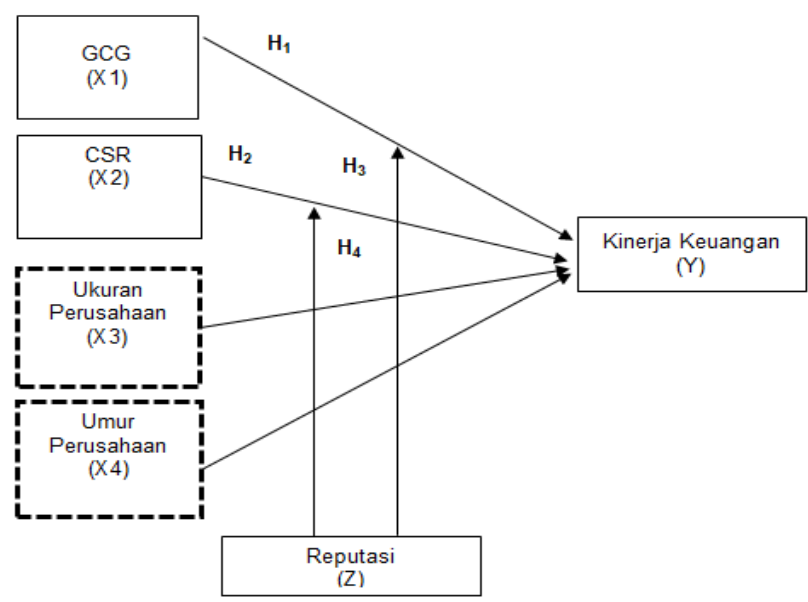

Fig 1:- Research Conceptual Framework 


\section{RESEARCH METHODS}

This research is a type of comparative causal research or often called a causal study (casual study) that is research that aims to investigate the causal relationship. Causal studies are at the core of a scientific approach to research where studies test whether one variable causes other variables to change or not (Sekaran and Bougie, 2017). Based on the type of data collected, this study uses a quantitative approach with the aim of the study is to test the hypotheses that have been set and show the direction of the relationship between variables based on the construction of the research model that has been built. This study explains the effect of the independent variable on the dependent variable to meet the hypothesis with the aim of providing empirical evidence about the effect of implementing GCG and CSR disclosure on financial performance and company reputation as a moderating variable.

Source of population and sample data using annual and financial reports of state-owned enterprises (BUMN) on the Indonesia Stock Exchange in 2014-2019. The population in this study is 20 state-owned companies listed on the IDX. The data analysis is used. The multiple regression test in this study is intended to see how the implementation of GCG and CSR disclosure, on financial performance (ROE) and is moderated by reputation.

The equations of the multiple moderation regression model can be expressed in the following equations.

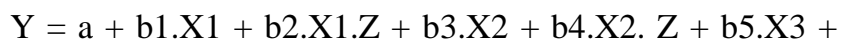

The $\mathrm{F}$ test aims to determine the model in fit condition. F test was done by looking at the significance value of $F$ with a significance level of 0.05 . The output results show that the significance of the $\mathrm{F}$ test is equal to 0,000 . F test results stated a significance value of less than 0.05 . The results of the analysis state that the regression model is in a fit condition. If the regression model is stated in a fit condition, it means that the model is in a testable and good condition. Analysis of the F test is based on the results of data processing.

$\mathrm{T}$ test was conducted to state the effect of one independent variable individually in explaining the variation of the dependent variable.

\section{RESULTS}

Hypothesis testing uses multiple regression analysis. A summary of the results of multiple regression is presented in the table below.

\begin{tabular}{|c|c|c|c|}
\hline \multicolumn{4}{|c|}{$\begin{array}{c}Y=a+b 1 \cdot X 1+b 2 \cdot X 1 \cdot Z+b 3 \cdot X 2+b 4 \cdot X 2 \cdot Z+b 5 \cdot X 3+b 6 \cdot X 4+\varepsilon \\
Y=6,627-15,305 \times 1+0,198 \times 1 \cdot Z+0,006 \times 2-0,003 \times 2 \cdot Z+0,020 X 3+0,083 \times 44\end{array}$} \\
\hline Variable & Coefficient & t-Statistic & Sig. \\
\hline Constanta & 6,627 & 0,962 & 0.339 \\
\hline $\mathrm{X} 1$ & $-15,305$ & $-1,108$ & 0,271 \\
\hline $\mathrm{X} 1 . \mathrm{Z}$ & 0,198 & 1,632 & 0,106 \\
\hline $\mathrm{X} 2$ & 0,006 & 2,151 & $0,034^{*}$ \\
\hline $\mathrm{X} 2 . \mathrm{Z}$ & $-0,003$ & $-1,800$ & 0,075 \\
\hline $\mathrm{X} 3$ & 0,020 & 2,199 & $0,030^{*}$ \\
\hline $\mathrm{X} 4$ & 0,083 & 2,718 & $0,008^{*}$ \\
\hline \multicolumn{4}{|c|}{ 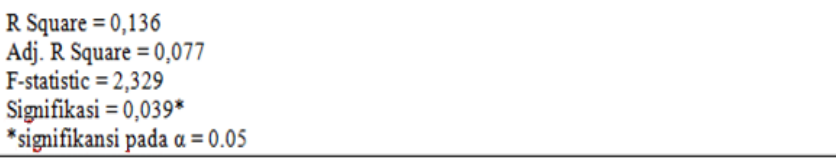 } \\
\hline \multicolumn{4}{|c|}{$\begin{array}{l}\text { The dependent variable is Financial Performance; Independent variables are GCG, GCG * } \\
\text { REPUTATION, CSR, CSR * REPUTATION, COMPANY SIZE and AGE COMPANY; and the } \\
\text { control variable is REPUTATION }\end{array}$} \\
\hline
\end{tabular}

Table 1:- Regression Test Results

Testing multiple linear regression in this study, testing the effect of GCG, CSR, Company Size, and Age of the Company on Financial Performance. In table 2 the coefficient of determination coefficient shown by $\mathrm{R} \neg$ Squared from the regression equation in the model used, produces a value of 0.136 This value can be explained that $13 \%$ of the independent variables consisting of GCG, CSR, Company Size, and Age of the Company supported by Reputation as a control variable is able to explain the Financial Performance variable. The remaining $87 \%$ is explained by other variables outside the model. This means that there are still other factors that greatly influence the earnings persistence variable.

In the simultaneous significance test shown by the Fstatistic, the value generated by the regression equation in the research model is 2.329 with a significance below $\alpha=0.05$, 0.039. It can be explained that GCG, CSR, Company Size, and Company Age supported by Reputation as control variables simultaneously influence the financial performance variables.

Based on table 1 The results of multiple regression obtained constants from the research model regression equation that is 6.627 . The result of the constant value states that without the influence of GCG, CSR, Company Size, Company Age and Reputation, the average company will increase financial performance by $66 \%$.

In the results of hypothesis testing, there are five hypotheses that are built. The following is a summary of the results of the hypothesis test shown in table 2 . 
ISSN No:-2456-2165

\begin{tabular}{|c|c|c|c|c|}
\hline Research Hypothesis & Coefficient & Direction Prediction & Significance & Results \\
\hline $\mathrm{H}_{1}$ & $-15,305$ & Negative & Not significant & Rejected \\
\hline $\mathrm{H}_{2}$ & 0,006 & Positive & significant & Received \\
\hline $\mathrm{H}_{3}$ & 0,198 & Positive & Not significant & Rejected \\
\hline $\mathrm{H}_{4}$ & $-0,003$ & Negative & Not significant & Rejected \\
\hline
\end{tabular}

Table 2:- Hypothesis Test Results

Good Corporate Governance (GCG) shows that there is an influence on financial performance that has a negative pattern so that the more the value of GCG, the smaller the value of financial performance. The GCG coefficient value of -15.305 means that every GCG increases by $1 \%$, the financial performance will decrease by $15 \%$. The results of regression analysis for the effect of GCG on financial performance showed a probability of $0.271>0.050$. This value indicates that the relationship between GCG and financial performance has no significant effect. Thus, it can be concluded that the first hypothesis stating GCG has a positive effect on financial performance, was rejected.

The regression coefficient of the CSR variable shows that there is an influence on financial performance that has a positive pattern so that the more the value of CSR increases, the greater the value of financial performance. The CSR coefficient value of 0.006 means that every CSR increases by $1 \%$, the financial performance will increase by $0.006 \%$. The results of regression analysis for the influence of CSR on financial performance showed a probability of $0.034<0.050$. This value indicates that the relationship between CSR and financial performance has a significant effect. Thus, it can be concluded that the second hypothesis stating CSR has a positive effect on financial performance, was accepted.

The value of the regression coefficient for the influence of reputation in moderating the relationship between GCG on financial performance shows a positive direction so that the more the value of reputation increases the value of GCG so that financial performance will increase. The reputation coefficient value in moderating the relationship between GCG and financial performance is 0.198 , meaning that each reputation increases by $1 \%$, it will weaken the relationship of GCG and financial performance by $0.19 \%$. The results of the regression analysis for the effect of reputation in moderating the relationship between GCG on financial performance showed a probability of $0.106>0.050$. This value indicates that the influence of reputation in moderating the relationship between GCG on financial performance is not significant. Thus, it can be concluded that the third hypothesis stating reputation has a positive and significant effect in moderating the relationship between GCG and financial performance, is rejected.

The value of the regression coefficient for the influence of reputation in moderating the relationship between CSR on financial performance shows a negative direction so that the more the value of reputation increases the further the value of CSR decreases so that financial performance will decrease further. The value of the reputation coefficient in moderating the relationship between CSR and financial performance is -0.003 , meaning that each reputation increases by $1 \%$, it will weaken the relationship of CSR and financial performance by $0.003 \%$. That is, reputation is not able to moderate the relationship between CSR and financial performance.

The results of the regression analysis for the effect of reputation in moderating the relationship between CSR on financial performance showed a probability of $0.075>0.050$. This value indicates that the influence of reputation in moderating the relationship between CSR on financial performance is not significant. Thus, it can be concluded that the third hypothesis stating reputation has a positive effect in moderating the relationship between GCG and financial performance, is rejected.

\section{DISCUSSION}

A. Implementation of Good Corporate Governance (GCG) has a positive effect on financial performance.

H1 test results indicate that Good Corporate Governance (GCG) has a negative and not significant effect on financial performance. The results of regression analysis for the effect of GCG on financial performance showed a probability of $0.271>$ 0.050 . This value indicates that the relationship between GCG and financial performance has no significant effect. This is likely due to the low awareness of issuers implementing GCG and the company's management has not been interested in the long-term benefits of implementing GCG because it has not seen any direct financial impact.

The results of this study are in line with the results of research by Iswara (2012),Novrianti and Armas (2012) which show that GCG with proxy for Managerial Ownership, Institutional Ownership, Board of Directors Size, Audit Committee Size has no significant influence on financial performance. This is due to the following things in Novrianti and Armas (2012): (1) Low awareness of issuers implementing GCG. They apply not because of necessity, but because of compliance with existing rules. (2) Company management is not yet interested in the long-term benefits of implementing GCG. They feel that they can run without GCG. (3) Company management has not seen any direct financial impact (4) Ownership issues, which are still partly concentrated in individuals or founding families. If BUMN is owned by the government, the commissioner cannot be independent and independent in overseeing management performance.

The results of this study are not in line with the results of research by Ariyani and Gunawan (2014), Purwani (2010) and Agustina et al. (2015) which shows that GCG variables have an influence on the value of financial performance with the ROA proxy. GCG with a measurement mechanism is managerial ownership will lead to allegations that the higher 
managerial ownership will improve the company's financial performance.

\section{B. Disclosure Disclosure of Corporate Social Responsibility (CSR) has a positive effect on financial performance.}

The regression coefficient of the CSR variable shows that there is an influence on financial performance that has a positive pattern so that the more the value of CSR increases, the greater the value of financial performance. The results of regression analysis for the influence of CSR on financial performance showed a probability of 0.034 $<0.050$. This value indicates that the relationship between CSR and financial performance has a significant effect. By implementing CSR, the company's image will be better, so that customer satisfaction is higher and so is the loyalty of consumers. The existence of a company's concern for the community that is high makes the public trust and investor interest in the company is higher. High investor interest has an impact on income or high profitability in terms of financial performance. High CSR is not a burden, but it is a social investment. Thus the implementation of CSR, can improve financial performance.

The results of this study are in line with the research results of Ariyani and Gunawan (2014), Malau et al., (2018), Djamilah and Surenggono (2017) and Agustina et al. (2015) which shows that partially CSR variables have a positive and significant effect on ROA and ROE as a proxy for Financial Performance. In theory CSR should be considered by investors before investing, because it contains social information that has been carried out by the company. With CSR reporting and disclosure, stakeholders can evaluate how CSR is implemented and give awards / sanctions to the company according to the results of its evaluation.

But the results of this study are not in line with Yaparto, et al. (2013) which shows that CSR does not significantly influence the Company's Financial Performance on ROA indicators. Likewise with Hapsari (2015) and Novrianti (2012) which show that CSR variables do not have a significant influence on financial performance. According to Novrianti (2012), this is due to the lack of CSR disclosure made by manufacturing companies that are sampled in this study so that it has no influence on financial performance and there is no standardization for the implementation of CSR by the Indonesian government.

\section{Reputation Has a Positive Impact in Moderating the Relationship Between GCG on Financial Performance.}

Regression coefficient values for the effect of reputation in moderating the relationship between GCG on financial performance shows a positive direction but not significant so it can be concluded that reputation is not able to moderate the relationship between GCG on financial performance and the effect of reputation in moderating the relationship between GCG on financial performance is not significant.
GCG in this research is in the form of public ownership, which is the proportion of company shares owned by the public, and institutional ownership, which means that shareholders are in the form of entities such as banking, insurance, pension funds, mutual funds and other institutions. Institutional investors are generally quite large shareholders because they have large funding. High levels of public and institutional ownership lead to high oversight efforts to obstruct opportunistic managerial behavior and can reduce agency problems.

GCG in the form of public ownership and high institutional ownership encouraged the emergence of demands to care about the environment around the company Humanitisri and Ghozali (2018). The public or the community as the company's shareholders not only want high corporate profits, but also want the company to play a role in social responsibility. Thus, high GCG will encourage high CSR so as to encourage high financial performance. However, the results of this study indicate that GCG has no influence on financial performance and reputation is not able to moderate the relationship between GCG and financial performance.

The results of this hypothesis also show the results of hypothesis one research which shows that there is no significant effect between the relationship of GCG on financial performance. This might be due to the market not paying attention to the implementation of corporate governance in the company or the implementation of corporate governance cannot be direct or short term but requires time and information about implementing corporate governance in a period of several years. So the reputation variable is not able to moderate the relationship between GCG and financial performance.

D. Reputation has a positive influence in moderating the relationship between CSR and financial performance.

The value of the regression coefficient for the effect of reputation in moderating the relationship between CSR on financial performance shows a negative direction so it can be concluded that reputation is not able to moderate the relationship between CSR on financial performance and the effect of reputation in moderating the relationship between CSR on financial performance is not significant. This might be due to the lack of corporate attention that is the object of research on social interests such as charitable donations, developing products that do not cause pollution, providing equal opportunities to employees, forming foundations, and other activities related to social and environmental so the company so that the impact on the reduction the company's financial performance in the long run.

The results of this study are not in line with the results of research by Humanitisri and Ghozali (2018) which shows that the indirect relationship between CSR and financial performance with reputation mediation variables has a $\mathrm{P}-$ Value of 0.02 , the significance used in this study is P-Value 0.05 , so the hypothesis is concluded received. The value of the path coefficients is 0.145 , it shows that if there is an increase in CSR value mediated by the company's reputation by one unit, the financial performance will increase by 0.145 , and vice 
versa if the CSR value mediated by the company's reputation decreases by one unit, the company's reputation will decrease by 0.145 .

According to Flanagan and Shaughnessy (2005), among the variables that mediate the relationship between CSR and financial performance, company reputation is one of the variables that is most considered because reputation is a strategic resource of the company. CSR activities conducted by the company can provide positive value and enhance the company's image. Increasing the company's image, the results of production and services of the company will be more accepted by consumers or the public, so the long-term impact will certainly increase economic growth and profitability of the company.

\section{CONCLUSION}

Based on the results of hypothesis testing and discussion of the effect of GCG and CSR on financial performance moderated by the company's reputation, the following conclusions can be drawn. The test results show that Good Corporate Governance does not affect financial performance. These results indicate that GCG does not contribute to the company's financial performance. The regression coefficient of the variable Corporate Social Responsibility shows that there is an influence on financial performance so that the more the value of CSR increases, the greater the value of financial performance. These results indicate that CSR contributes to the company's financial performance. Regression coefficient values indicate that there is no influence of reputation in moderating the relationship between GCG on financial performance. These results indicate that reputation is not able to moderate the relationship between GCG and financial performance. Regression coefficient values indicate that there is no influence of reputation in moderating the relationship between CSR on financial performance. These results indicate that reputation is not able to moderate the relationship between CSR and financial performance.

\section{REFERENCES}

[1]. Agustina, W., Yuniarta, G. A., Sinarwati, \& Kadek, N. (2015). Pengaruh Intellectual Capital, Corporate Governance dan Corporate Social Responsibility Terhadap Kinerja Keuangan. E-Journal Akuntansi Universitas Pendidikan Ganesha, 3(1), 1-11.

[2]. Akerlof, G. A. (1970). The Market for "Lemons": Quality Uncertainty and the Market Mechanism. The Quarterly Journal of Economics, 84(3), 488500.

[3]. Ariyani, R. D., \& Gunawan, J. (2014). Pengaruh Pengungkapan Good Corporate Governance dan Corporate Social Responsibility Terhadap Kinerja Perusahaan Perbankan. E-Journal Magister Akuntansi Trisakti, 1(September), 181-198.
[4]. Barney, J. (1991). Firm Resources and Sustained Competitive Advantage. Journal of Management, 17(1), 99-120. https://doi.org/10.1177/014920639101700108

[5]. Djamilah, S., \& Surenggono, S. (2017). Corporate Social Responsibility Sebagai Variabel Pemediasi Pengaruh Good Corporate Governance Terhadap Kinerja Keuangan. AKRUAL: Jurnal Akuntansi, 9(1), 41. https://doi.org/10.26740/jaj.v9n1.p41-53

[6]. Egwuonwu, R. C. I. (2011). Corporate Reputation \& Firm Performance: Empirical Literature Evidence. International Journal of Business and Management, 6(4), 197-206. https://doi.org/10.5539/ijbm.v6n4p197

[7]. Fatimah, Mardani, R. M., \& Wahono, B. (2017). Pengaruh Good Corporate Governance Terhadap Nilai Perusahaan Dengan Kinerja Keuangan Sebagai Variabel Intervening. E-Jurnal Riset Manajemen Prodi Manajemen, 51-69.

[8]. Fitriani, luthfilia D., \& Hapsari, D. W. (2015). Pengaruh Good Corporate Governance dan Corporate Social Responsibility Terhadap Kinerja Keuangan Perusahaan. E-Proceeding of Management, 2(3), 34583474.

[9]. Heal, G. (2004). Corporate Social Responsibility, An Economic and Financial Framework. Paul Garret Professor of Public Policy and Corporate Responsibility Columbia Business School.

[10]. Humanitisri, N., \& Ghozali, I. (2018). Perusahaan sebagai Variabel Mediasi, dan Visibilitas sebagai Variabel Moderasi dalam Hubungan antara CSR dengan Reputasi ( Studi Empiris pada Perusahaan Manufaktur yang Terdaftar di Bursa Efek Indonesia Periode 20152016 ). Diponegoro Journal of Accounting, 7, 1-13.

[11]. Iswara, P. W. (2014). Corporate Governance dan Kinerja Perusahaan. Jurnal Akuntansi , Ekonomi Dan Manajemen Bisnis ISSN : 2337-7887, 2(2), 121-131.

[12]. Jensen, M. C., \& Meckling, W. H. (1976). Theory of the Firm: Managerial Behavior, Agency Costs and Ownership Structure. Journal of Financial Economics, 3(4), 305-360.

[13]. Lee, J., \& Roh, J. J. (2012). Revisiting corporate reputation and firm performance link. Benchmarking, 19(4), 649-664. https://doi.org/10.1108/14635771211258061

[14]. Malau, N. S., Tugiman, H., \& Budiono, E. (2018). Pengaruh Good Corporate Governance Dan Corporate Social Responsibility Terhadap Kinerja Santoso, A. (2017). Pengaruh Good Corporate Governance Terhadap Nilai Perusahaan Dengan Kinerja Keuangan Sebagai Variabel Intervening. Prosiding Seminar Nasional Dan Call For Paper Ekonomi Dan Bisnis, Oktober, 66-67. https://doi.org/10.1111/14622920.14261

[15]. Misani, N. (2017). The Organizational Outcomes of Corporate Social Responsibility: A Review of the Literature. SSRN Electronic Journal. https://doi.org/10.2139/ssrn.2968787 
[16]. Novrianti, V., \& Armas, R. (2012). Pengaruh Corporate Social Responsibility Dan Good Corporate Governance Terhadap Kinerja (Studi Pada Perusahaan Manufaktur di BEI Tahun 20092011). Jurnal Akuntansi, 1(1), 1-11.

[17]. Phandeirot, M. (2017). Pengaruh CEO Duality , Earning Management dan Corporate Reputation terhadap Financial Performance pada Perusahaan yang Terdaftar di Bursa Efek Indonesia. Petra Business \& Management Review, 3(1), 117-134.

[18]. Purwani, T. (2010). Pengaruh Good Corporate Governance Terhadap Kinerja Perusahaan. Majalah Ilmiah Informatika, 1(2), 47-60.

[19]. Putri, N. G. A. P. S., \& Hatane, S. E. (2016). Pengaruh Corporate Reputation Terhadap Financial Performance Melalui Innovation Capability Sebagai Intervening Variable pada Industri Perhotelan di Surabaya. Journal of Chemical Information and Modeling, 4(1), 458-468. https://doi.org/10.1017/CBO9781107415324.004

[20]. Ramdhaningsih, A., \& Utama, I. M. K. (2013). Pengaruh Indikator Good Corporate Governance dan Profitabilitas Pada Pengungkapan Corporate Social Responsibility. E-Jurnal Akuntansi, 3(2), 368-386.

[21]. Roberts, P. W., \& Dowling, G. R. (2002). Corporate Reputation and Sustained Superior Financial Performance. Strategic Management Journal, 23(12), 1077-1093. https://doi.org/10.1002/smj.274

[22]. Saeidi, S. P., Sofian, S., Saeidi, P., Saeidi, S. P., \& Saaeidi, S. A. (2015). How does Corporate Social Responsibility Contribute to Firm Financial Performance? The Mediating Role of Competitive Advantage, Reputation, and Customer Satisfaction. Journal of Business Research, 68(2), 341-350. https://doi.org/10.1016/j.jbusres.2014.06.024

[23]. Santoso, A. (2017). Pengaruh Good Corporate Governance Terhadap Nilai Perusahaan Dengan Kinerja Keuangan Sebagai Variabel Intervening. Prosiding Seminar Nasional Dan Call For Paper Ekonomi Dan Bisnis, Oktober, 66-67. https://doi.org/10.1111/1462-2920.14261

[24]. Sekaran, U., \& Bougie, R. (2017). Metode Penelitian untuk Bisnis (6th ed.). Jakarta: Salemba Empat.

[25]. Siam, Y. I. S. A., Laili, N. H. B., \& Khairi, K. F. Bin. (2014). Board of directors and earnings management among Jordanian listed companies: proposing conceptual framework. International Journal of Technical Research, 2(3), 1-7. Retrieved from http://www.ijtra.com/special-issue-view/boardof-directors-and-earnings-management-amongjordanian-listed-companies-proposing-conceptualframework.pdf

[26]. Shi, Y. (2016). Reputation, financial performance, and industry competition. The International Journal of Business and Finance Research, 10(2), 1-16.
[27]. Suchman, M. C. (1995). Managing Legitimacy: Strategic and Institutional Approaches. Academy of Management Review, 20(3), 571-610. Retrieved from http://citeseerx.ist.psu.edu/viewdoc/download?doi=10.1. $1.108 .2768 \& \mathrm{rep}=\mathrm{rep} 1 \&$ type $=\mathrm{pdf}$

[28]. Sutedi, A. (2011). Good Corporate Governance. Jakarta: Sinar Grafika.

[29]. Widjaja, A., \& Tunggal, I. S. (2012). Memahami Konsep Corporate Governance. Jakarta: Havarindo.

[30]. Wijs, N. (2013). Finance: A quantitative Introduction (2016th ed.). Cambridge: Cambridge University Press TOP Brand Award.

[31]. Yaparto, M., K, D. F., \& Eriandani, R. (2013). Pengaruh Corporate Social Responsibility Terhadap Kinerja Keuangan Pada Sektor Manufaktur Yang Terdaftar Di Bursa Efek Indonesia Pada Periode 2010-2011. Calyptra: Jurnal Ilmiah Mahasiswa Universitas Surabaya, 2(1), 1-19. 